\title{
Privatization and environmental policy in a mixed oligopoly*
} Privatización y política medioambiental en un oligopolio mixto

\author{
QUAN Dong** \\ JuAn CARLos BÁRCENA-Ruiz*** \\ MARÍA BEGOÑA GARZÓN****
}

\begin{abstract}
This paper analyzes the interaction between two political economy decisions by a government: whether to privatize a public firm and what environmental policy to choose (an environmental tax or an emission standard). We find that when market competition is weak the government does not privatize the public firm and sets an environmental tax. When it is intermediate the public firm is not privatized and the government sets an environmental standard. Finally, when market competition is strong the government privatizes the public firm and is indifferent between a tax and a standard.
\end{abstract}

Key words: Environmental tax, emission standard, mixed oligopoly, privatization.

JEL Classification: Q58, L13, L32, H2.

\footnotetext{
* We thank two referees for helpful comments. Financial support from Ministerio de Ciencia y Tecnología (ECO2015-66803-P) and Grupos de Investigación UPV/EHU (GIU17/051) is gratefully acknowledged.

** South China Normal University, School of Economics and Management, Higher Education Mega Center, Guangzhou 510006, P. R. China. E-mail: dongquan@scnu.edu.cn

*** [Corresponding author] Universidad del País Vasco UPV/EHU. Avenida Lehendakari Aguirre 83; 48015 Bilbao, Spain. E-mail: juancarlos.barcena@ehu.es

**** Universidad del País Vasco UPV/EHU. Avenida Lehendakari Aguirre 83; 48015 Bilbao, Spain. E-mail: mariabegona.garzon@ehu.es
}

Received: July, 2017. Accepted: September, 2018. 


\section{Resumen}

Este artículo analiza la interacción entre dos decisiones de economía política que tiene que tomar un gobierno: si privatizar una empresa pública y qué política ambiental elegir (un impuesto medioambiental o un estándar de emisiones). Encontramos que cuando la competencia de las empresas en el mercado es débil, el gobierno no privatiza la empresa pública y establece un impuesto medioambiental. Cuando es intermedia, la empresa pública no se privatiza y el gobierno establece un estándar medioambiental. Finalmente, cuando la competencia en el mercado es fuerte, el gobierno privatiza la empresa pública y está indiferente entre un impuesto y un estándar.

Palabras clave: Impuesto medioambiental, estándar, oligopolio mixto, privatización

Clasificación JEL: Q58, L13, L32, H2.

\section{INTRODUCTION}

In many industries in current economies there is interaction between private and public firms. Oil, heavy manufacturing, telecommunications and tourism are good examples of mixed oligopolies (De Fraja, 2009). This is especially important in Europe, where governments still own a significant percentage of the firms in different sectors of industry (see Parker, 1998; Parker and Saal, 2003).

Since the 1980s there has been a worldwide wave of privatization of public firms (Matsumura and Shimizu, 2010). In 1979 the United Kingdom privatized many of its state corporations and more privatizations, albeit on a smaller scale, followed in the rest of the European Community in the 1980's. In the 1990's the creation of the Single Market sparked further privatization. To explain this evidence, the literature on mixed oligopoly has analyzed the decision by governments of whether to privatize a single public firm (see, for example, De Fraja and Delbono, 1989, 1990; Corneo and Jeanne, 1994). These papers have been extended to consider, among other factors, partial privatization of public firms (Matsumura, 1998; Lin and Matsumura, 2012), privatization and mergers (Méndez-Naya, 2007, 2012), privatization of state-holding corporations (Bárcena-Ruiz and Garzón, 2017; Dong et al., 2018), and privatization with switching costs (Dong and Bárcena-Ruiz, 2017).

The above cited papers do not assume explicitly that firms pollute the environment, so the environmental policies of governments are ignored when it is decided whether to privatize public firms ${ }^{1}$. However, this is an important factor

\footnotetext{
Bluffstone and Panayotou (2000) analyze the decision by governments of whether to privatize a public firm when on-site contamination and potential environmental liabilities are significant. However, they do not consider that governments implement an environmental policy.
} 
in the privatization of public firms in mixed markets such as public airlines, automobile, steel, chemical, power plant, waste disposal, transportation, and so on, which emit pollutants in the production process. In this regard, Lovei and Gentry (2002) point out that evidence from Central and Eastern Europe, Latin America, and Asia reveals positive links between privatization of public firms and improved environmental performance. It is in the best interest of governments to integrate environmental issues into the privatization process in order to achieve sustainable outcomes. For example, Bulgaria, after the transition to a market economy started, privatized some of public firms and adopted the Environmental protection Act of 1991, which provided a new foundation for environmental management. In 1990 Germany privatized many public firms that belonged to the former East Germany. Ongoing environmental liabilities were transferred to the new owners. Moreover, some EU countries, such as the Scandinavian countries ${ }^{2}$, France, Belgium, The Netherlands and Germany, have privatized some of their public firms (Parker, 1998; Parker and Saal, 2003) and at the same time are concerned about the environment and use environmental policies to protect it (see European Environment Agency, 2000, 2005) ${ }^{3}$.

Since the 1990's increasing concern over the quality of the environment has led governments to set environmental policies to control pollution. Economic literature that analyzes the environment assuming private oligopolies has studied optimal environmental taxes and standards under imperfect competition (Helfand, 1999; Requate, 2006; Ohori, 2011; Bárcena-Ruiz and Campo, 2017). Helfand (1999) argues that if firms are identical and there is no uncertainty taxes and standards generate the same social welfare. However, Baumol and Oates (1988, ch. 4) find that taxes are superior when firms differ ${ }^{4}$. Helfand (1999) also argues that the greater efficiency of taxes over standards depends on several factors such as, for example, how standards are formulated, whether there are information asymmetries, and how conditions change over time ${ }^{5}$.

2 The Norwegian government uses nationalization or privatization as a tool to improve the environment in addition to the environmental policy. This last includes environmental taxes and environmental standards. For example, the fund owned by the Norwegian state sold its shares in Rio Tinto, the world's second-biggest mining firm, for fear that this mine caused environmental damage abroad (see The Economist, January 22, 2009, available at: http://www.economist.com/node/12970769).

3 Another example is the steel industry in Taiwan. China Steel Corporation (CSC) is a state-owned corporation that competes against the private steel firm Yueh United Steel Corporation (YUSCO) in the domestic market. In 1995, CSC was privatized by the government of Taiwan. The productive process of these two firms, located in Kaohsiung, pollutes the environment of this city and the government was very concerned about it. Thus, the government of Taiwan proposed green taxes to mitigate the increasing environmental damage (Wang et al., 2009).

4 When firms have different abatement costs, and when the abatement level depends only on total emissions, abatement costs are higher with a standard than with a tax.

5 Heuson (2010) finds that taxes have a comparative advantage over standards when imperfect competition and uncertain abatement costs are assumed. Lahiri and Ono (2007) 
The above papers have been extended to consider a mixed market. Wang et al. (2009) analyze the optimal degree of privatization in a mixed duopoly when the government sets environmental taxes to control pollution ${ }^{6}$. Ohori (2006) analyzes the same problem in an international duopoly. Naito and Ogawa (2009) show that in a mixed duopoly welfare under an emission standard is greater than under an environmental tax, regardless of the degree of partial privatization. Finally, Kato (2011) shows that the superiority of environmental taxes over emission standards in a mixed duopoly depends on the parameters of the cost functions.

In a mixed duopoly the public firm is usually not privatized since market competition is greatly reduced. The above cited papers analyze the environmental policies of governments assuming a mixed duopoly, so they cannot analyze how they affect the decision by governments to privatize public firms. In fact, only partial privatization can be analyzed. Thus, the objective of this paper is to examine the environmental policy instrument preferred by governments, in a mixed oligopoly, when public firms can be privatized.

To analyze the above issue we assume a single market with $n$ private firms and one public firm that produce a homogeneous good with the same technology. The production process of the firms pollutes the environment, but producers have technology available for abating this pollution, and that technology is the same for all firms. There is a government that may set an environmental tax or an emission standard to control pollution and that decides whether to privatize the public firm or not. We find that the superiority of the environmental tax over the emission standard depends on the number of private firms that compete in the market. When that number is low the public firm is not privatized and social welfare is greater with an environmental tax. When the number of private firms takes an intermediate value the public firm is not privatized but social welfare is greater with an emission standard. Finally, if the number of private firms is high the public firm is privatized and the government is indifferent between an environmental tax and an emission standard.

The paper most closely related to our own is that of Kato (2011), who shows that in a mixed duopoly the superiority of an environmental tax over an emission standard depends on the parameters of the cost functions. Moreover, he obtains that the government does not privatize the public firm since he considers a mixed duopoly. We extend his work by considering a mixed oligopoly, which enables us to analyze the decision by governments of whether to privatize focusing on how that decision is affected by the environmental policy instrument chosen to control pollution. We find that the superiority of an environmental tax over an emission

show that a relative emission standard is welfare-superior to an emission-equivalent tax when the number of firms is fixed, assuming one country and imperfect competition.

6 Bárcena-Ruiz and Garzón (2006) compare the optimal pollution tax in a mixed oligopoly with that chosen in a private oligopoly when domestic firms are assumed. Kato (2013) analyzes the optimal degree of privatization in a mixed duopoly when there is an environmental problem but the government does not implement an environmental policy. 
standard depends on market competition, measured by the number of private firms competing in the market, a factor that is not considered by Kato (2011).

The rest of the paper is organized as follows. Section 2 presents the model. Sections 3 and 4 analyze the decision of whether to privatize the public firm when the government sets an environmental tax and an emission standard, respectively. Section 5 shows the main result of the paper, and Section 6 draws conclusions.

\section{THE MODEL}

We consider an industry made up of one public firm, denoted by firm 0 , which competes with $n$ private firms $(n \geq 1)$ producing a homogeneous good and that engage in Cournot competition. As usual, the public firm aims to maximize social welfare and private firms to maximize their own profits. If the public firm is privatized there are $n+1$ private firms in the market. The inverse demand function of the good is given by $p=1-Q$, where $p$ is the price of the good, $Q=q_{0}+\sum_{i=1}^{n} q_{i}$ is the total output of industry, $q_{0}$ is the output produced by the public firm, and $q_{i}$ is the amount of the good produced by private firm $i$, $i=1, \ldots, n$. Firms have the same production cost function given by $C\left(q_{i}\right)=c q_{i}^{2}$, $i=0,1, \ldots, n$.

Each unit of output produced by the private firms and the public firm causes one unit of pollutant. The production by firm $i$ generates total pollution emissions $e_{i}$. Producers have technology available for abating this pollution, and that technology is the same for all the firms. The abatement level chosen by firm $i$ is denoted by $a_{i}$. The pollution abatement cost function of firm $i$ is given by $C A_{i}=k a_{i}^{2}, i=0,1, \ldots, n$. If firm $i$ chooses output level $q_{i}$ and pollution abatement level $a_{i}$, pollutant emissions by firm $i$ are $e_{i}=q_{i}-a_{i}{ }^{7}$. The environmental damage in the economy caused by the output of the firms is given by: $E D=d\left(\sum_{i=0}^{n} e_{i}\right)^{2}$, where the positive parameter $d$ measures the valuation of the environment by the government.

To protect the environment the government may choose between two environmental policy instruments: an environmental tax or an emission standard. In the first case the government imposes a tax, $t$, per unit of pollutant emitted. Thus, the taxes that firm $i$ has to pay are $t e_{i}$, and the tax revenue collected by the government is $T=t \sum_{i=0}^{n} e_{i}$. In the second case the government imposes a uniform upper bound on pollution that limits the pollutant that firms may emit, which is denoted by $s$. In that case, firms do not pay environmental taxes. Therefore, the profit of firm $i$ when an environmental tax is set is:

7 It can be shown that the equilibrium pollution emissions of firm i are always positive. 


$$
\pi_{i}=\left(1-q_{i}-\sum_{j=0, j \neq i}^{n} q_{j}\right) q_{i}-c q_{i}^{2}-t e_{i}-k a_{i}^{2}, i=0,1, \ldots, n .
$$

When the government sets an environmental standard, $s$, the firm has to abate all emissions above $s$. Thus, the profit of firm $i$ is:

$$
\pi_{i}=\left(1-q_{i}-\sum_{j=0, j \neq i}^{n} q_{j}\right) q_{i}-c q_{i}^{2}-k\left(q_{i}-s\right)^{2}, i=0,1, \ldots, n .
$$

As usual, the producer and consumer surpluses are $P S=\pi_{0}+\sum_{i=1}^{n} \pi_{i}$ and $C S=\left(q_{0}+\sum_{i=1}^{n} q_{i}\right)^{2} / 2$, respectively. The social welfare function that the government considers comprises the consumer surplus $(C S)$, the producer surplus $(P S)$, the pollution tax revenue $(T)$, if any, and the environmental damage, $E D$. It is given by:

$$
W=C S+P S+T-E D \text {. }
$$

To analyze how different environmental policy instruments affect the government's decision on privatization, we consider a three-stage game. In the first stage the government simultaneously decides whether to privatize the public firm or not, and whether to set up an environmental tax or an emission standard. If the public firm is privatized the market structure is a private oligopoly but if it is not privatized the market structure is a mixed oligopoly. In the second stage, given the decisions taken in the first stage, the government chooses the optimal tax, $t$, or the optimal standard, $s$. In the third stage firms act simultaneously and non-cooperatively to choose outputs and abatement levels. We solve the game by backward induction to obtain a subgame perfect Nash equilibrium. To simplify the exposition of results, and with no loss of generality, we assume $c=k=d=1^{8}$.

Next, we analyze the government's decision on whether to privatize the public firm by assuming that the government sets an environmental tax to control pollution.

\section{ENVIRONMENTAL TAX}

Let subscript $t$ denote that the government sets an environmental tax to protect the environment. This means that the case faced is that analyzed by Bárcena-Ruiz and Garzón (2006). We consider first that the government does not privatize the public firm, so there is a mixed oligopoly. In the third stage of the game the public firm chooses $q_{0}$ and $a_{0}$ to maximize the social welfare given

8 It can be shown that the main results of the paper hold when the values of these parameters change. 
by (3), and each private firm $i$ chooses $q_{i}$ and $a_{i}$ to maximize its own profit given by (1). Solving these problems, we obtain:

$$
q_{0}=\frac{6-2 n+(7+n) n t}{4(6+n)}, q_{i}=\frac{6-(8+n) t}{4(6+n)}, a_{0}=\frac{6+(4-(13+2 n) t) n}{8(6+n)}, a_{i}=\frac{t}{2}, i=1, \ldots, n .
$$

Given the number of private firms in the market, the output of the public firm $q_{0}$ (the output of each private firm $q_{i}$ ) increases (decreases) with the environmental tax $t$. The abatement level of the public firm $a_{0}$ (that of each private firm $a_{i}$ ) decreases (increases) with $t$. In order to increase social welfare the public firm increases its output and reduces its abatement level, which further reduces the output produced by each private firm since outputs are strategic substitutes.

In the second stage of the game, given (4), the government chooses the environmental tax $t$ to maximize social welfare. Solving this problem we obtain the following result.

Lemma 1: When the government sets an environmental tax and the public firm is not privatized, in equilibrium,

$$
\begin{gathered}
t=\frac{36+46 n+6 n^{2}}{208+198 n+45 n^{2}+3 n^{3}}, q_{0 t}=\frac{52+34 n+4 n^{2}}{208+198 n+45 n^{2}+3 n^{3}}, q_{i t}=\frac{40+26 n+3 n^{2}}{208+198 n+45 n^{2}+3 n^{3}}, \\
a_{0 t}=\frac{52+56 n+7 n^{2}}{416+396 n+90 n^{2}+6 n^{3}}, a_{i t}=\frac{18+23 n+3 n^{2}}{208+198 n+45 n^{2}+3 n^{3}}, \pi_{i t}=\frac{3524+4988 n+2469 n^{2}+450 n^{3}+27 n^{4}}{\left(208+198 n+45 n^{2}+3 n^{3}\right)^{2}}, \\
\pi_{0 t}=\frac{15184+21392 n+10528 n^{2}+1916 n^{3}+115 n^{4}}{4\left(208+198 n+45 n^{2}+3 n^{3}\right)^{2}}, C S_{t}=\frac{\left(52+74 n+30 n^{2}+3 n^{3}\right)^{2}}{2\left(208+198 n+45 n^{2}+3 n^{3}\right)^{2}}, \\
P S_{t}=\frac{15184+35488 n+30480 n^{2}+11792 n^{3}+1915 n^{4}+108 n^{5}}{4\left(208+198 n+45 n^{2}+3 n^{3}\right)^{2}}, E D_{t}=\frac{\left(52+56 n+7 n^{2}\right)^{2}}{4\left(208+198 n+45 n^{2}+3 n^{3}\right)^{2}}, \\
T_{t}=\frac{\left(18+23 n+3 n^{2}\right)\left(52+56 n+7 n^{2}\right)}{\left(208+198 n+45 n^{2}+3 n^{3}\right)^{2}}, W_{t}=\frac{52+80 n+33 n^{2}+3 n^{3}}{416+396 n+90 n^{2}+6 n^{3}}, i=1, \ldots, n .
\end{gathered}
$$

Next, we consider that the government privatizes the public firm, so there is a private oligopoly. Let superscript $P$ denote that the public firm is privatized, which means that there are $n+1$ private firms competing in the market. In the third stage each firm $i$ chooses $q_{i}$ and $a_{i}$ to maximize its own profit given by (1). Solving this problem, we obtain:

$$
q_{i}=\frac{1-t}{4+n}, a_{i}=\frac{t}{2}, i=0,1, \ldots, n .
$$

It is easy to show that, given $n$, when the environmental tax $t$ increases, the extent to which $q_{i}$ decreases is less in this case than in the mixed oligopoly. 
In the second stage the government chooses environmental tax $t$ to maximize the social welfare given by (3). Solving this problem, we obtain the following result.

Lemma 2: When the government sets an environmental tax and the public firm is privatized, in equilibrium,

$$
\begin{gathered}
t^{P}=\frac{2\left(5+7 n+n^{2}\right)}{58+58 n+14 n^{2}+n^{3}}, q_{i t}^{P}=\frac{12+8 n+n^{2}}{58+58 n+14 n^{2}+n^{3}}, a_{i t}^{P}=\frac{5+7 n+n^{2}}{58+58 n+14 n^{2}+n^{3}}, \\
\pi_{i t}^{P}=\frac{313+454 n+235 n^{2}+46 n^{3}+3 n^{4}}{\left(58+58 n+14 n^{2}+n^{3}\right)^{2}}, E D_{t}^{P}=\frac{(1+n)^{2}(7+n)^{2}}{\left(58+58 n+14 n^{2}+n^{3}\right)^{2}}, \\
C S_{t}^{P}=\frac{(1+n)^{2}\left(12+8 n+n^{2}\right)^{2}}{2\left(58+58 n+14 n^{2}+n^{3}\right)^{2}}, P S_{t}^{P}=\frac{(1+n)\left(313+454 n+235 n^{2}+46 n^{3}+3 n^{4}\right)}{\left(58+58 n+14 n^{2}+n^{3}\right)^{2}}, \\
T_{t}^{P}=\frac{2(1+n)(7+n)\left(5+7 n+n^{2}\right)}{\left(58+58 n+14 n^{2}+n^{3}\right)^{2}}, \quad W_{t}^{P}=\frac{14+23 n+10 n^{2}+n^{3}}{2\left(58+58 n+14 n^{2}+n^{3}\right)}, i=0,1, \ldots, n .
\end{gathered}
$$

Next we study whether the government privatizes the public firm or not. By comparing the social welfare obtained in the private and mixed oligopolies we find that $W_{t}^{P} \geq W_{t}$ if and only if $n \geq n_{t}$, where $n_{t}=(\sqrt{105}-1) / 2 \approx 4.6$. Thus, the following result is obtained.

Proposition 1 (Bárcena-Ruiz and Garzón, 2006): In equilibrium, under an environmental tax the government privatizes the public firm if and only if $n \geq n_{t}$.

\section{Proof: See Appendix}

As in Bárcena-Ruiz and Garzón (2006), we compare the results obtained in the mixed and private oligopolies and obtain that the output of industry is greater in the mixed oligopoly since the government cares about the consumer surplus, which leads to a greater consumer surplus in the mixed oligopoly $\left(C S_{t}>C S_{t}^{P}\right)$.

The public firm produces more than each firm in the private oligopoly, which means that the public firm abates and emits more than each private firm. Moreover, the private firms in the mixed oligopoly produce, abate, and emit less than in the private oligopoly. Compared with the case of the private oligopoly, the higher emission level of the public firm offsets the lower emission level of the private firms, and thus total emissions are greater in the mixed oligopoly. This means the greater environmental damage is obtained in the mixed oligopoly $\left(E D_{t}>E D_{t}^{P}\right)$.

Raising the environmental tax reduces the output of the private firms. Moreover, given that they have to compete with a public firm the private firms reduce their 
output further in the mixed oligopoly than in the private one. As a result, the government levies a lower tax in the mixed oligopoly $\left(t<t^{P}\right)$. However, total taxes collected by the government are greater in the mixed oligopoly $\left(T_{t}>T_{t}^{P}\right)$ since total emissions are greater in that case.

As the public firm is more aggressive in the product market than the private firms, private firms obtain more profit in the private oligopoly. Moreover, the profit of the public firm is reduced due to quadratic production and abatement costs. As a result, the producer surplus is greater in the private oligopoly than in the mixed oligopoly $\left(P S_{t}^{P}>P S_{t}\right)$.

Comparing the welfare obtained in the two cases we find that when market competition is weak $\left(n<n_{t}\right)$ the government does not privatize the public firm since this would further reduce market competition. The greater consumer surplus and total taxes collected by the government in the mixed oligopoly $\left(C S_{t}>P S_{t}^{P}\right.$ and $\left.T_{t}>T_{t}^{P}\right)$ offset the lower producer surplus and the greater environmental damage $\left(P S_{t}<P S_{t}^{P}\right.$ and $\left.E D_{T}>E D_{t}^{P}\right)$. When the market is more competitive $\left(n>n_{t}\right)$ the government privatizes the public firm even though competition is reduced, since the effects of the lower environmental damage and greater producer surplus dominate.

Next, we analyze the government's decision on whether to privatize the public firm by assuming that the government sets an emission standard.

\section{EMISSION STANDARD}

Let subscript $s$ denote that the government sets an emission standard to control pollution. We consider first that the government does not privatize the public firm. When the government sets an emission standard, firms reduce their pollutant emissions by an amount sufficient to exactly meet the standard, since abating emissions is expensive. In the third stage of the game, private firm $i$ chooses $q_{i}$ so as to maximize its profit function, given by (2). The public firm chooses $q_{0}$ so as to maximize the social welfare function given by (3). Solving these problems, we obtain:

$$
q_{0}=\frac{5+10 s}{25+4 n}, q_{i}=\frac{4+8 s}{25+4 n}, \quad i=1, \ldots, n .
$$

In the second stage of the game the government chooses the emission standard $s$ that maximizes social welfare. Solving this problem we obtain the following.

Lemma 3: When the government sets an emission standard and the public firm is not privatized, in equilibrium,

$$
s=\frac{125+136 n+16 n^{2}}{1000+2003 n+1225 n^{2}+248 n^{3}+16 n^{4}}, q_{0 s}=\frac{5(25+4 n)(1+n)(2+n)}{1000+2003 n+1225 n^{2}+248 n^{3}+16 n^{4}},
$$




$$
\begin{gathered}
q_{i s}=\frac{4(25+4 n)(1+n)(2+n)}{1000+2003 n+1225 n^{2}+248 n^{3}+16 n^{4}}, C S_{s}=\frac{(5+4 n)^{2}(25+4 n)^{2}\left(2+3 n+n^{2}\right)^{2}}{2\left(1000+2003 n+1225 n^{2}+248 n^{3}+16 n^{4}\right)^{2}}, \\
\pi_{0 s}=\frac{109375+381000 n+506954 n^{2}+322748 n^{3}+101394 n^{4}+14800 n^{5}+800 n^{6}}{\left(1000+2003 n+1225 n^{2}+248 n^{3}+16 n^{4}\right)^{2}}, \\
\pi_{i s}=\frac{104375+364400 n+485776 n^{2}+309664 n^{3}+97328 n^{4}+14208 n^{5}+768 n^{6}}{\left(1000+2003 n+1225 n^{2}+248 n^{3}+16 n^{4}\right)^{2}}, \\
P S_{s}=\frac{109375+485375 n+871354 n^{2}+808524 n^{3}+411058 n^{4}+112128 n^{5}+15008 n^{6}+768 n^{7}}{\left(1000+2003 n+1225 n^{2}+248 n^{3}+16 n^{4}\right)^{2}}, \\
E D_{s}=\frac{\left(125+261 n+152 n^{2}+16 n^{3}\right)^{2}}{\left(1000+2003 n+1225 n^{2}+248 n^{3}+16 n^{4}\right)^{2}}, W_{s}=\frac{250+647 n+565 n^{2}+184 n^{3}+16 n^{4}}{2000+4006 n+2450 n^{2}+496 n^{3}+32 n^{4}}, i=1, \ldots, n .
\end{gathered}
$$

Under a private oligopoly, in the third stage of the game firm $i$ chooses $q_{i}$ so as to maximize its profit function given by (2). Solving, we obtain:

$$
q_{i}=\frac{1+2 s}{6+n}, i=0,1, \ldots, n
$$

In the second stage of the game the government chooses the standard $s$ that maximizes social welfare. Solving this problem we obtain the following.

Lemma 4: When the government sets an emission standard and the public firm is privatized, in equilibrium,

$$
\begin{gathered}
s^{P}=\frac{7+n}{58+58 n+14 n^{2}+n^{3}}, q_{i s}^{P}=q_{i t}^{P}, C S_{s}^{P}=C S_{t}^{P}, \pi_{i s}^{P}=\pi_{i t}^{P}+t^{P}\left(q_{i t}^{P}-t^{P} / 2\right), \\
P S_{s}^{P}=P S_{t}^{P}+T_{t}^{P}, E D_{s}^{P}=E D_{t}^{P}, W_{s}^{P}=W_{t}^{P}, i=0,1, \ldots, n .
\end{gathered}
$$

This Lemma shows that under an emission standard the producer surplus, the environmental damage, the consumer surplus and social welfare are the same as those obtained under environmental taxes. This is because firms are identical (see Helfand, 1999).

Next we study whether the government privatizes the public firm or not. By comparing the social welfare obtained in the private and mixed oligopolies we find that $W_{s}^{P} \geq W_{s}$ if and only if $n \geq n_{s}$, where $n_{s}=(3 \sqrt{14}-1) / 2 \approx 5.1$. Thus, the following result is obtained. 
Proposition 2: In equilibrium, under an emission standard the government privatizes the public firm if and only if $n \geq n_{s}{ }^{9}$.

Proof: See Appendix.

As under taxes, the output of industry is greater in the mixed oligopoly than in the private oligopoly because the government cares about the consumer surplus. This means that the greater consumer surplus is obtained in the mixed oligopoly $\left(C S_{s}>C S_{s}^{P}\right)$, while the greater producer surplus is obtained in the private oligopoly $\left(P S_{s}^{P}>P S_{s}\right)$.

Under an environmental tax firms have to pay a tax per unit of pollutant emitted. This means that the firms that produce more abate more emissions and pay more taxes, and the total emissions of public and private firms differ (since the public firm pollutes more). However, under an emission standard the government sets the same total emission level for all firms. When the number of private firms is low, market competition is also low in the private oligopoly. In the mixed oligopoly the public firm increases market competition by raising its output. As the output and thus the gross emissions of the public firm are high compared to those of the firms in the private oligopoly, there is a higher standard in the mixed oligopoly (i.e. $s>s^{P}$ ). When $n$ increases market competition also increases and the output of the public firm decreases. Thus, the output and gross emissions of the public firm are not so high as those of the firms in the private oligopoly. As a result, when $n$ is high $\left(n>n_{s}\right)$ the decrease in the output of the public firm implies that the standard is higher in the private oligopoly (i.e. $s<s^{P}$ ). Therefore $s>s^{P}$ if and only if $n<n_{s}$. As environmental damage depends positively on total emissions, environmental damage is greater in the mixed oligopoly if $n$ is low $\left(E D_{s}>E D_{s}^{P}\right.$ if $\left.n<n_{s}\right)$.

Comparing the welfare obtained in the two cases we find that when market competition is low $\left(n<n_{s}\right)$ the government does not privatize the public firm, since this would further reduce market competition. The greater consumer surplus in the mixed oligopoly $\left(C S_{s}>C S_{s}^{P}\right)$ offsets the lower producer surplus and the greater environmental damage $\left(P S_{s}^{P}>P S_{s}\right.$ and $\left.E D_{s}^{P}<E D_{s}\right)$. When $n$ is high $\left(n>n_{s}\right)$ the government privatizes the public firm, since the increase in the producer surplus dominates the reduction in market competition and the increase in environmental damage (now $\left.E D_{s}^{P}>E D_{s}\right)$.

9 There are examples of privatization in industries where competition is strong. For example, worldwide competition in the steel sector is strong due to the behaviour of Asian companies. In this sector, the Mexican government privatized the steel firm Sidermex (Lovei and Gentry, 2002, pp. 69). The obligations to undertake the actions to comply with the existing Mexican environmental requirements were transferred to the buyers as part of the privatization contracts. 


\section{Comparison Of RESUlts}

In the first stage of the game the government maximizes social welfare by deciding on privatization and choosing its environmental policy instrument. Before solving stage 1, a comparison of the social welfare obtained in the mixed oligopoly under an environmental tax and under an emission standard reveals that $W_{s} \geq W_{t}$ if and only if $n \geq n_{t s}$, where $n_{t s}=(\sqrt{21}-1) / 2 \approx 1.8$. Thus, the following result is obtained.

Proposition 3: In equilibrium, under a mixed oligopoly the government sets an emission standard if $n \geq n_{t s}$, otherwise it sets an environmental tax. ${ }^{10}$

\section{Proof: See Appendix}

In the mixed oligopoly the public firm produces more than the private firms since it cares about the consumer surplus. With a tax per unit of pollutant emitted, firms that produce and pollute more pay more taxes. However, under an emission standard all the firms face the same restriction on emissions. Firms therefore cannot produce as much as under taxes since their pollutant emissions are upper bounded and their abatement costs are quadratic. Under a tax, firms can produce and pollute more by paying more taxes to avoid abating emissions. As a result, under an emission standard the output of the public firm is lower and thus the output of each private firm is greater than under a tax. The lower output of the public firm dominates and, as a result, the output of industry is greater under a tax. As the consumer surplus increases with the output of industry, the greatest consumer surplus is obtained when the government sets an environmental tax $\left(C S_{t}>C S_{s}\right)$.

Under an environmental tax firms may pollute more by paying more taxes, but under an emission standard this is not possible since pollutant emissions are upper bounded. Thus, under a tax total emissions are greater than under a standard. As the environmental damage depends positively on total emissions, it is greater under a tax $\left(E D_{t}>E D_{s}\right)$. Given that the output of industry is greater under a tax than under a standard market competition is greater in the former case. Therefore, the profit of each firm is greater when the government sets a standard to control pollution, which means that $P S_{s}>P S_{t}$.

Comparing the welfare obtained in the mixed oligopoly with the two environmental policy instruments we find that when market competition is low $\left(n<n_{t s}\right)$ the government sets an environmental tax to control pollution. In this case the greater consumer surplus $\left(C S_{t}>C S_{s}\right)$ and the taxes levied by the government $\left(T_{t}>0\right)$ between them offset the lower producer surplus $\left(P S_{t}<P S_{s}\right)$ and the greater environmental damage $\left(E D_{t}>E D_{s}\right)$. When $n$ is high $\left(n>n_{t s}\right)$ the

10 The main result obtained in this proposition holds if we consider that the objective function of the government is a weighted welfare function (see Appendix). 
government sets an emission standard, since the greater producer surplus and the lower environmental damage offset the lower consumer surplus.

It is shown in the Lemma 4 that $W_{t}^{P}=W_{s}^{P}$. From Propositions 1 to 3 , the first stage of the game can be solved, with the following result.

Proposition 4: In equilibrium, the government does not privatize the public firm and sets an environmental tax if $n<n_{t s}$. The government does not privatize and sets an emission standard if $n_{t s} \leq n<n_{s}$. Finally, the government privatizes and is indifferent between an environmental tax and an emission standard if $n \geq n_{s} 11$.

According to Propositions 1 and 2, the government does not privatize the public firm when $n$ is low: under a tax when $n<n_{t}$ and under a standard when $n<n_{s}$. Moreover, Proposition 3 shows that when the government does not privatize the public firm it sets a tax if $n<n_{t s}$ and a standard if $n_{t s} \leq n<n_{s}$. Finally, if $n \geq n_{s}$ the public firm is privatized, and in that case the same welfare is obtained with the two environmental policy instruments.

\section{Conclusions}

Since the 1980's there has been a worldwide wave of privatization of public firms. In many countries where public firms have been privatized the governments use environmental policies to control pollution. Economic literature on optimal environmental taxes and emission standards in a mixed market has considered a mixed duopoly and thus cannot analyze how environmental policy instruments affect government decisions on privatization. To fill this gap in the literature, this paper analyzes the interaction between the decision on whether to privatize a public firm in a mixed oligopoly and the setting of environmental taxes or standards by the government.

We find that the result depends on market competition, measured by the number of private firms. The government does not privatize the public firm when market competition is low. In that case it is not true that the government always prefers a tax or a standard. We find that when the number of private firms is low the government sets an environmental tax, but when the number of private firms is intermediate it sets an emission standard. Finally, when market competition is high the government privatizes the public firm but is indifferent between a tax and a standard since both environmental instruments generate the same welfare.

11 The main result obtained in this proposition holds if we consider that the objective function of the government a weighted welfare function (see Appendix). 


\section{APPENDIX}

\section{Proof of Proposition 1:}

$$
\begin{gathered}
q_{i t}-q_{i t}^{P}=-\frac{(2+n)(4+n)(22+n(10+n))}{\left(58+58 n+14 n^{2}+n^{3}\right)\left(208+198 n+45 n^{2}+3 n^{3}\right)}<0, \\
Q_{t}-Q_{t}^{P}=\frac{520+772 n+388 n^{2}+76 n^{3}+5 n^{4}}{\left(58+58 n+14 n^{2}+n^{3}\right)\left(208+198 n+45 n^{2}+3 n^{3}\right)}>0, \\
T-t^{P}=-\frac{2(2+n)(-2+n(5+n)(7+n))}{\left(58+58 n+14 n^{2}+n^{3}\right)\left(208+198 n+45 n^{2}+3 n^{3}\right)}<0, \\
\pi_{i t}-\pi_{i t}^{P}=-\frac{(2+n)\left(843448+2045244 n+2102194 n^{2}+1186537 n^{3}+397228 n^{4}+80664 n^{5}+9748 n^{6}+645 n^{7}+18 n^{8}\right)}{\left(58+58 n+14 n^{2}+n^{3}\right)^{2}\left(208+198 n+45 n^{2}+3 n^{3}\right)^{2}}<0, \\
W_{t}^{P}-W_{t}=\frac{(2+n)\left(60112+92400 n+43136 n^{2}+51786 n^{3}+68138 n^{4}+36670 n^{5}+9740 n^{6}+1382 n^{7}+101 n^{8}+3 n^{9}\right)}{2(58+n(58+n(14+n)))(208+3 n(66+n(15+n)))}>0, \\
A=1543776+6387664 n+10519008 n^{2}+9263936 n^{3}+4829940 n^{4}+1544164 n^{5}+304556 n^{6}+36084 n^{7}+2354 n^{8}+65 n^{9}, \\
E D_{t}-E D_{t}^{P}=\frac{(2+n)\left(52+56 n+56 n^{2}+14 n^{3}+n^{4}\right)\left(5928+12364 n+8596 n^{2}+2400 n^{3}+292 n^{4}+13 n^{5}\right)}{4\left(58+58 n+14 n^{2}+n^{3}\right)^{2}\left(208+198 n+45 n^{2}+3 n^{3}\right)^{2}}>0, \\
2\left(58+58 n+14 n^{2}+n^{3}\right)^{2}\left(208+198 n+45 n^{2}+3 n^{3}\right)^{2}
\end{gathered}
$$

\section{Proof of Proposition 2:}

$$
\begin{aligned}
& q_{i s}-q_{i s}^{P}=-\frac{(2+n)\left(200+490 n+297 n^{2}+61 n^{3}+4 n^{4}\right)}{\left(58+58 n+14 n^{2}+n^{3}\right)\left(1000+2003 n+1225 n^{2}+248 n^{3}+16 n^{4}\right)}<0, \\
& Q_{s}-Q_{s}^{P}=\frac{(1+n)(2+n)(1250+n(1192+5 n(57+4 n)))}{\left(58+58 n+14 n^{2}+n^{3}\right)\left(1000+2003 n+1225 n^{2}+248 n^{3}+16 n^{4}\right)}>0,
\end{aligned}
$$




$$
\begin{gathered}
\pi_{i s}-\pi_{i s}^{P}=\frac{-B}{\left(58+58 n+14 n^{2}+n^{3}\right)^{2}\left(1000+2003 n+1225 n^{2}+248 n^{3}+16 n^{4}\right)^{2}}<0, \text { where } \\
B=(2+n)\left(15941250+76140075 n+153362604 n^{2}+170048590 n^{3}+114214642 n^{4}+48453923 n^{5}+\right. \\
C S_{s}-C S_{s}^{P}=\frac{(1+n)^{2}(2+n)^{2}\left(1250+1192 n+285 n^{2}+20 n^{3}\right)\left(13250+27228 n+18991 n^{2}+5446 n^{3}+688 n^{4}+32 n^{5}\right)}{2\left(58+58 n+14 n^{2}+n^{3}\right)^{2}\left(1000+2003 n+1225 n^{2}+248 n^{3}+16 n^{4}\right)^{2}}>0, \\
P S_{s}-P S_{s}^{P}=-\left(( 1 + n ) ( 2 + n ) \left(7531250+44013875 n+101823108 n^{2}+124420454 n^{3}+89533074 n^{4}+\right.\right. \\
\left.\left.39900619 n^{5}+11258736 n^{6}+2009813 n^{7}+219806 n^{8}+13440 n^{9}+352 n^{10}\right)\right) / \\
\left(\left(58+58 n+14 n^{2}+n^{3}\right)^{2}\left(1000+2003 n+1225 n^{2}+248 n^{3}+16 n^{4}\right)^{2}\right)<0, \\
E D_{s}-E D_{s}^{P}=-\frac{(1+n)^{2}(2+n)\left(-125+4 n+4 n^{2}\right)\left(14250+30159 n+21144 n^{2}+5918 n^{3}+720 n^{4}+32 n^{5}\right)}{\left(58+58 n+14 n^{2}+n^{3}\right)^{2}\left(1000+2003 n+1225 n^{2}+248 n^{3}+16 n^{4}\right)^{2}}>0 \text { if } \\
n<n_{s}=(3 \sqrt{14}-1) / 2 \approx 5.1 . \\
s-s^{P}=-\frac{(1+n)(2+n)^{2}(-125+4 n(1+n))}{\left(58+58 n+14 n^{2}+n^{3}\right)\left(1000+2003 n+1225 n^{2}+248 n^{3}+16 n^{4}\right)}>0 \text { if } n<n_{s} \\
-W_{s}^{P}=-\frac{1}{2\left(58+58 n+14 n^{2}+n^{3}\right)\left(1000+2003 n+1225 n^{2}+248 n^{3}+16 n^{4}\right)}<0 \text { if } n<n_{s} .
\end{gathered}
$$

\section{Proof of Proposition 3:}

$$
\begin{gathered}
q_{0 s}-q_{0 t}=-\frac{n(2+n)(1168+n(1367+n(488+n(73+4 n))))}{\left(208+198 n+45 n^{2}+3 n^{3}\right)\left(1000+2003 n+1225 n^{2}+248 n^{3}+16 n^{4}\right)}<0, \\
q_{i s}-q_{i t}=\frac{(2+n)(800+n(868+n(287+n(53+4 n))))}{\left(208+198 n+45 n^{2}+3 n^{3}\right)\left(1000+2003 n+1225 n^{2}+248 n^{3}+16 n^{4}\right)}>0, \\
Q_{s}-Q_{t}=-\frac{n(2+n)(368+n(499+n(201+20 n)))}{\left(208+198 n+45 n^{2}+3 n^{3}\right)\left(1000+2003 n+1225 n^{2}+248 n^{3}+16 n^{4}\right)}<0,
\end{gathered}
$$

$\pi_{i s}-\pi_{i t}=\left(991680000+5257417600 n+11854281848 n^{2}+14892708672 n^{3}+11500695810 n^{4}+\right.$ $\left.5705914822 n^{5}+1857681899 n^{6}+400145932 n^{7}+56506565 n^{8}+5036560 n^{9}+257424 n^{10}+5760 n^{11}\right) /$ $\left(\left(208+198 n+45 n^{2}+3 n^{3}\right)^{2}\left(1000+2003 n+1225 n^{2}+248 n^{3}+16 n^{4}\right)^{2}\right)>0$,

$P S_{s}-P S_{t}=\left(3744000000+23717952000 n+65288187168 n^{2}+102545248640 n^{3}+101611147548 n^{4}+\right.$ $66465039700 n^{5}+29289422009 n^{6}+8758319342 n^{7}+1773361741 n^{8}+239157444 n^{9}+20580520 n^{10}+$ $\left.1023360 n^{11}+22400 n^{12}\right) /\left(4\left(208+198 n+45 n^{2}+3 n^{3}\right)^{2}\left(1000+2003 n+1225 n^{2}+248 n^{3}+16 n^{4}\right)^{2}\right)>0$, 


$$
\begin{gathered}
C S_{s}-C S_{t}=-n(2+n)^{2}\left(368+499 n+201 n^{2}+20 n^{3}\right)\left(52000+151788 n+165345 n^{2}+83513 n^{3}+20066 n^{4}+\right. \\
\left.2256 n^{5}+96 n^{6}\right) /\left(2\left(208+198 n+45 n^{2}+3 n^{3}\right)^{2}\left(1000+2003 n+1225 n^{2}+248 n^{3}+16 n^{4}\right)^{2}\right)<0 . \\
E D_{s}-E D_{t}=-n(2+n)\left(1040+1995 n+1217 n^{2}+248 n^{3}+16 n^{4}\right)\left(104000+318232 n+360706 n^{2}+186605 n^{3}+\right. \\
\left.44877 n^{4}+4984 n^{5}+208 n^{6}\right) /\left(4\left(208+198 n+45 n^{2}+3 n^{3}\right)^{2}\left(1000+2003 n+1225 n^{2}+248 n^{3}+16 n^{4}\right)^{2}\right)<0, \\
W_{s}-W_{t}=\frac{2 n(2+n)^{2}\left(-5+n+n^{2}\right)}{\left(208+198 n+45 n^{2}+3 n^{3}\right)\left(1000+2003 n+1225 n^{2}+248 n^{3}+16 n^{4}\right)}>0 \text { if } n>n_{t s}=(\sqrt{21}-1) / 2 \approx 1.8 .
\end{gathered}
$$

Weighted welfare function: We consider now that the social welfare function is given by the following function: $W=\alpha C S+P S+T-E D$. Therefore, we consider a weighted welfare function, where $\alpha$ is the weight attached to the consumer surplus. We assume that $5>\alpha \geq 1$ to assure that the output of the firms, the emission level and the critical values of $n$ are positive in all the cases. Solving similarly to when $\alpha=1$, we obtain:

$$
\begin{gathered}
W_{t}=\frac{(2+n)\left(13(5-\alpha)-2 n^{2}\left(1-5 \alpha+\alpha^{2}\right)+2 n\left(29-\alpha-\alpha^{2}\right)\right)}{2\left(6 n^{3}+n^{2}(110-20 \alpha)+26(5-\alpha)^{2}+n\left(580-201 \alpha+17 \alpha^{2}\right)\right)}, \\
W_{s}=\frac{\left(2+3 n+n^{2}\right)\left(25(6-\alpha)+4 n\left(35-\alpha^{2}\right)-4 n^{2}\left(1-6 \alpha+\alpha^{2}\right)\right)}{2\left(16 n^{4}+8 n^{3}(36-5 \alpha)+50\left(30-11 \alpha+\alpha^{2}\right)+n^{2}\left(1660-468 \alpha+33 \alpha^{2}\right)+n\left(2900-980 \alpha+83 \alpha^{2}\right)\right)}, \\
W_{t}^{P}=\frac{\left(2+3 n+n^{2}\right)(6+\alpha+n \alpha)}{2\left(60+14 n^{2}+n^{3}+2 n(30-\alpha)-2 \alpha\right)}, W_{s}^{P}=\frac{\left(2+3 n+n^{2}\right)(6+\alpha+n \alpha)}{2\left(60+14 n^{2}+n^{3}+2 n(30-\alpha)-2 \alpha\right)} .
\end{gathered}
$$

By comparing the welfare obtained in the different cases, we obtain the following:

i) $W_{t}^{P} \geq W_{t}$ if and only if $n \geq n_{t \alpha}$, where $n_{t \alpha}=(\sqrt{131-26 \alpha}-1) / 2$,

ii) $W_{s}^{P} \geq W_{s}$ if and only if $n \geq n_{s \alpha}$, where $n_{s \alpha}=(\sqrt{151-25 \alpha}-1) / 2$,

iii) $W_{s} \geq W_{t}$ if and only if $n \geq n_{t s \alpha}$, where $n_{t s \alpha}=\left(\sqrt{31-11 \alpha+\alpha^{2}}-1\right) / 2$,

iv) $n_{s \alpha}>n_{t \alpha}>n_{t s \alpha}>0$ for $5>\alpha \geq 1$. 


\section{REFERENCES}

Bárcena-Ruiz, J.C., and M.L. Campo (2017). “Taxes versus standards under cross-ownership", Resource and Energy Economics, Vol. 50; 36-50.

Bárcena-Ruiz, J.C., and M.B. Garzón (2006). "Mixed oligopoly and environmental policy", Spanish Economic Review, Vol. 8; 139-160.

Bárcena-Ruiz, J.C., and M.B. Garzón (2017). "Privatization of state holding corporations", Journal of Economics, Vol. 120; 171-188.

Baumol, W.J., and W.E. Oates (1988). The theory of environmental policy. Cambridge, U.K.: Cambridge University Press.

Bluffstone, R., and T. Panayotou (2000). "Environmental liability in Central and Eastern Europe: Toward an optimal policy", Environmental and Resource Economics, Vol. 17; 335-352.

Corneo, G., and O. Jeanne (1994). "Oligopole mixte dans un marché commun”, Annales d'Economie et de Statistique, Vol. 33; 73-90.

De Fraja, G., and F. Delbono (1989). "Alternatives strategies of a public enterprise in oligopoly", Oxford Economic Papers, Vol. 41; 302-311.

De Fraja, G., and F. Delbono (1990). "Game theoretic models of mixed oligopoly", Journal of Economic Surveys, Vol. 4; 1-17.

De Fraja, G. (2009). "Mixed oligopoly: old and new", Working Paper No 09/20, University of Leicester.

Dong, Q., and J.C. Bárcena-Ruiz (2017). "Privatization and entry with switching costs”, The Manchester School, Vol. 85; 491-510.

Dong, Q.; J.C. Bárcena-Ruiz, and M.B. Garzón (2018). "Partial privatization of state holding corporations", The Manchester School, Vol. 86;119-138.

European Environment Agency (2000). "Environmental taxes: Recent developments in tools for integration", Environmental Issues Series, N ${ }^{\circ} 18$.

European Environment Agency (2005). "Market-based instruments for environmental policy in Europe", EEA Technical Report No 8/2005.

Helfand, G.E. (1999). "Standards versus taxes in pollution control" In: van der Bergh J. (ed.), Handbook of Environmental and Resource Economics, Ch. 15, Cheltenham UK and Northampton MA, USA.: Edward Elgar.

Heuson, C. (2010). "Weitzman revisited: emission standards versus taxes with uncertain abatement costs and market power of polluting firms", Environmental Resource and Economics, Vol. 47; 349-369.

Kato, K. (2011). "Emission quota versus emission tax in a mixed duopoly", Environmental Economics and Policy Studies, Vol. 13; 43-63.

Kato, K. (2013). "Optimal degree of privatization and the environmental problem", Journal of Economics, Vol. 110; 165-180.

Lahari, S., and Y. Ono (2007). "Relative emission standard versus tax under oligopoly: The role of free entry", Journal of Economics, Vol. 91; 107-128.

Lin, M. H., and T. Matsumura (2012). "Presence of Foreign Investors in Privatized Firms and Privatization Policy", Journal of Economics, Vol. 107; 71-80. 
Lovei, M., and B.S. Gentry (2002). The Environmental Implications of Privatization. Lesson for Developing countries. World Bank Discussion Papers $\mathrm{N}^{\circ}$ 426. The World Bank. Washington D.C.

Matsumura, T. (1998). "Partial privatization in mixed duopoly", Journal of Public Economics, 70; 473-483.

Matsumura, T., and D. Shimizu (2010). "Privatization waves", The Manchester School, Vol. 78; 609-625.

Méndez-Naya, J. (2007). "Privatización y fusiones en oligopolios mixtos", Estudios de Economía, Vol. 34; 37-52.

Méndez-Naya, J. (2012). "Fusiones nacionales e internacionales en oligopolios mixtos", Estudios de Economía, Vol. 39; 87-104.

Naito, T., and H. Ogawa (2009). "Direct versus indirect environmental regulation in a partially privatized mixed duopoly", Environmental Economics and Policy Studies, Vol. 10; 87-100.

Ohori, S. (2006). "Optimal environmental tax and level of privatization in an international duopoly", Journal of Regulatory Economics, Vol. 29; 225-233.

Ohori, S. (2011). "Environmental policy instruments and foreign ownership", Environmental Economics and Policy Studies, Vol. 13; 65-78.

Parker, D. (1998). Privatisation in the European Union. Theory and policy perspectives. London and New York: Routledge.

Parker, D., and D. Saal (2003). International handbook of privatization. Edward Elgar Publishing.

Requate, T. (2006). "Environmental policy under imperfect competition", in T. Tietenberg and H. Folmer (eds.), The International Yearbook of Environmental and Resource Economics 2006/2007. A Survey of Current Issues, Edward Elgar.

Wang, L.F.S.; Y. Wang and L. Zhao (2009). "Privatization and the environment in a mixed duopoly with pollution abatement", Economics Bulletin, Vol. 29; 3112-3119. 